\title{
Growth, Gas Exchanges and Maize Productivity Under Potassic Fertilizer Management and Residual Response on Bean
}

\author{
João Everthon da Silva Ribeiro (Corresponding Author) \\ Center for Agricultural Sciences, Federal University of Paraíba, Areia, Paraiba, Brazil \\ Email: j.everthon@hotmail.com \\ Manoel Felix da Silva Neto \\ Center for Agricultural Sciences, Federal University of Paraíba, Areia-PB, Brazil \\ Email: mfelix.agro@gmail.com
}

José Marcelino da Silva Júnior

Federal Rural University of Pernambuco, Garanhuns, Pernambuco, Brazil

Email: marcelinojunioragro@gmail.com

Manoel Bandeira de Albuquerque

Center for Agricultural Sciences, Federal University of Paraíba, Areia-PB, Brazil

Email: bandeira1977@gmail.com

Guilherme Silva de Podestá

Center for Agricultural Sciences, Federal University of Paraíba, Areia-PB, Brazil

Email: oguipodesta@yahoo.com.br

Fábio Mielezrski

Center for Agricultural Sciences, Federal University of Paraíba, Areia-PB, Brazil

Email: mfabioagro@gmail.com 


\section{MlMacrothink}

Received: August 8, 2019

doi:10.5296/jas.v7i4.15236
Journal of Agricultural Studies

ISSN 2166-0379

2019, Vol. 7, No. 4

Accepted: August 21, 2019

Published: August 29, 2019

URL: https://doi.org/10.5296/jas.v7i4.15236

\begin{abstract}
Potassium $(\mathrm{K})$ is the second nutrient of greater absorption by plants, and it is of fundamental importance for the development of the cultures and acts in the activation of enzymes that participate in the photosynthetic processes. However, there are still doubts about its residual effect on crop succession. Therefore, the objective of the research was to evaluate the effect of $\mathrm{K}$ doses on growth, gas exchange and maize yield and its residual effect on bean culture. The experiment was a randomized complete block design, in a $5 \times 2$ factorial scheme, totaling 10 treatments, with five $\mathrm{K}$ doses $\left(0,50,100,150\right.$ and $\left.200 \mathrm{~kg} \mathrm{ha}^{-1}\right)$ and two fertilization periods (seeding and V5 stadium) in maize plants. Growth parameters, gas exchange and yield were evaluated in maize plants, and growth was evaluated in Bean plants in an experimental area belonging to the Department of Plant Science and Environmental, Federal University of Paraíba in Northeast Brazil. For the analysis of the data, we performed the analysis of variance, according to the design adopted. Subsequently, the data were submitted to regression analysis, with curve fitting, according to the parameters evaluated. Results revealed that, $\mathrm{K}$ fertilization influenced the growth of maize plants in the two fertilization periods (seeding and V5 stadium) at 45 and 75 days after planting, as well as in gas exchange and productivity. Fertilization at the V5 stadium in maize presented higher values compared to fertilization at seeding, in which the dose of $150 \mathrm{~kg} \mathrm{ha}^{-1}$ presented the best results at both planting times. In relation to the residual effect of $\mathrm{K}$ on bean growth, it was verified that, there was influence of the doses on the growth of plants, in which the dose of $200 \mathrm{~kg} \mathrm{ha}^{-1}$ recorded the highest values. The results showed that there is the residual response of $\mathrm{K}$ on bean cultivation in succession with maize. For the greater development of maize, it is recommended to use the dose of $150 \mathrm{~kg} \mathrm{ha}^{-1}$ at the V5 stage of plants.
\end{abstract}

Keywords: potassic fertilizer, maize productivity, gas exchange, residual response

\title{
1. Introduction
}

Potassium $(\mathrm{K})$ is the second nutrient with the greatest absorption by plants, with fundamental importance for the development of the cultures, and it becomes effective in the activation of enzymes that participate in the photosynthetic and respiratory processes (Raij et al., 1997; Vilela et al., 2004; Taiz et al., 2017). According to Benites et al. (2010), the levels of K in tropical soils are generally considered low, and it is necessary the use of potassic fertilizers to supply the necessity required by the cultures. Deficiency of this nutrient may lead to reduction of internodes, apical dominance and plant growth, as well as directly affect productivity, in order to produce smaller fruits (Ernani et al., 2007). Such deficiency occurs due to inadequate soil management, occurring after a few years of cultivation (Cavalli \& Lange, 2018).

The absence or insufficient application of K may cause nutrient exhaustion in the soil, and excessive application may increase the leaching loss, also occurring in soils with medium and 
high CEC (cation exchange capacity) (Ernani et al., 2007). The cycling of $\mathrm{K}$ in the soil occurs soon after plant senescence, because $\mathrm{K}$ is present in the ionic form $\left(\mathrm{K}^{+}\right)$(Pavinato et al., 2008).

The residual effect of $\mathrm{K}$ depends on the amount exported by the crops and also on the leaching process (Parente et al., 2016). Ferreira et al. (2011) emphasize that the nutrients that are available to plants depend on soil fertility and residue degradation, and that in intensive cultivations, $\mathrm{K}$ absorption by the plant remains for most of the time in the plant tissue, without leaching or erosion. Thus, abiotic factors, such as temperature and humidity of the air, directly affect the rate of release of $\mathrm{K}$ in the soil (Parente et al., 2016).

In the maize crop, $\mathrm{K}$ affects mainly the grain mass and the number of grains per spike (Coelho et al., 2007), and it is the second nutrient most absorbed by the crop, with $30 \%$ exported by the grains. The responses of maize to $\mathrm{K}$ in field experiments with direct planting were less frequent than studies with phosphate and nitrogen fertilization, due to the low productivity indexes that were observed (Coelho et al., 2006). This author verified that $\mathrm{K}$ fertilization provided increases in yield using doses of up to $120 \mathrm{~kg} \mathrm{ha}^{-1} \mathrm{de} \mathrm{K}_{2} \mathrm{O}$ in soils with low levels of $\mathrm{K}$.

In the bean culture the $\mathrm{K}$ absorption, in favorable conditions, provides a greater development of the grains in the period of maturation and in the vigor of the seeds (Oliveira et al., 1996). For bean culture, $\mathrm{K}$ is the nutrient extracted and exported in large quantities, and in most soils where commercial exploitation takes place, low levels of this nutrient are registered (Sousa et al., 2013). Melo et al. (2005) states that although K does not present significant responses in most trials, it has been confirmed that doses between 20 and 40 are responsible for high $\mathrm{K}$ concentrations in plant tissues.

In view of the above, the present study is based on the hypothesis that the use of increasing doses of $\mathrm{K}$ in maize provides a greater residual effect on the bean culture. From this, the objective was to evaluate the effect of $\mathrm{K}$ doses on growth, gas exchange and maize yield and its residual effect on bean culture.

\section{Material and Method}

\subsection{Study Area, Experimental Design and Cultivation}

The work was carried out in an experimental area belonging to the Department of Plant Science and Environmental, Federal University of Paraíba, Campus II, located in the city of Areia, in the micro-region of Brejo and mesoregion of wild regions in Paraíba, state of

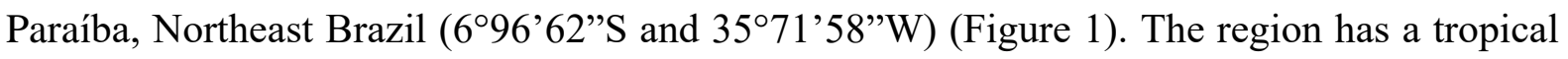
climate, with high rainfall in the months of June and July (Ribeiro et al., 2018), classified according to Peel et al. (2007) as Aw'. It presents variable altitude between 400 and 600 meters, average annual temperature $22^{\circ} \mathrm{C}$ and annual rainfall of $1,400 \mathrm{~mm}$.

The research was carried out from April to June (maize crop) and from September to November (bean crop) of 2017. The climatic data regarding precipitation (mm), mean temperature $\left({ }^{\circ} \mathrm{C}\right)$ and relative humidity of the air $(\%)$, during the period of conduction of the experiment, are described in Figure 2. 


\section{Macrothink}
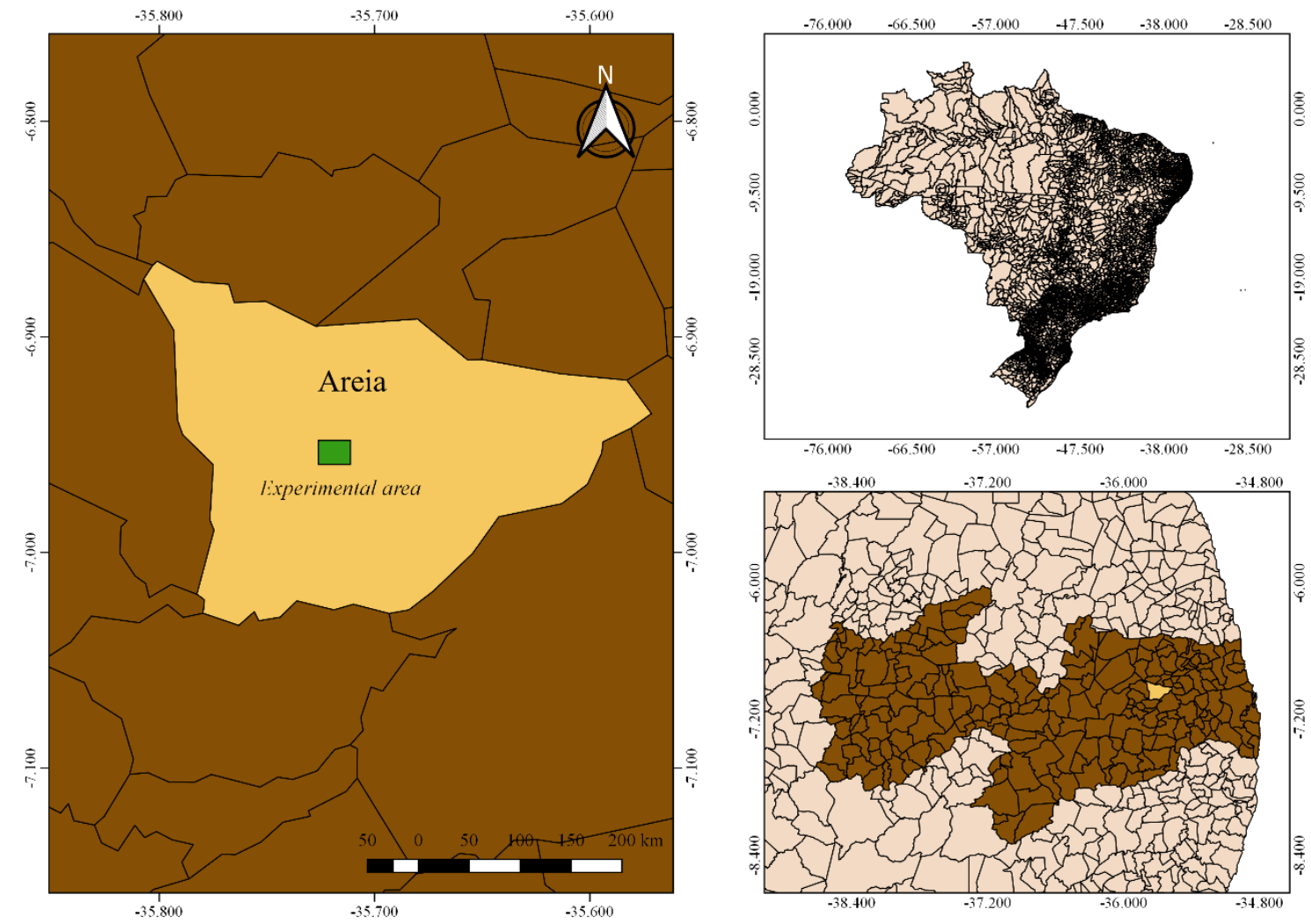

Figure 1. Geographic location of the experimental area, located at the Federal University of Paraíba, municipality of Areia, Paraíba, Northeast Brazil 


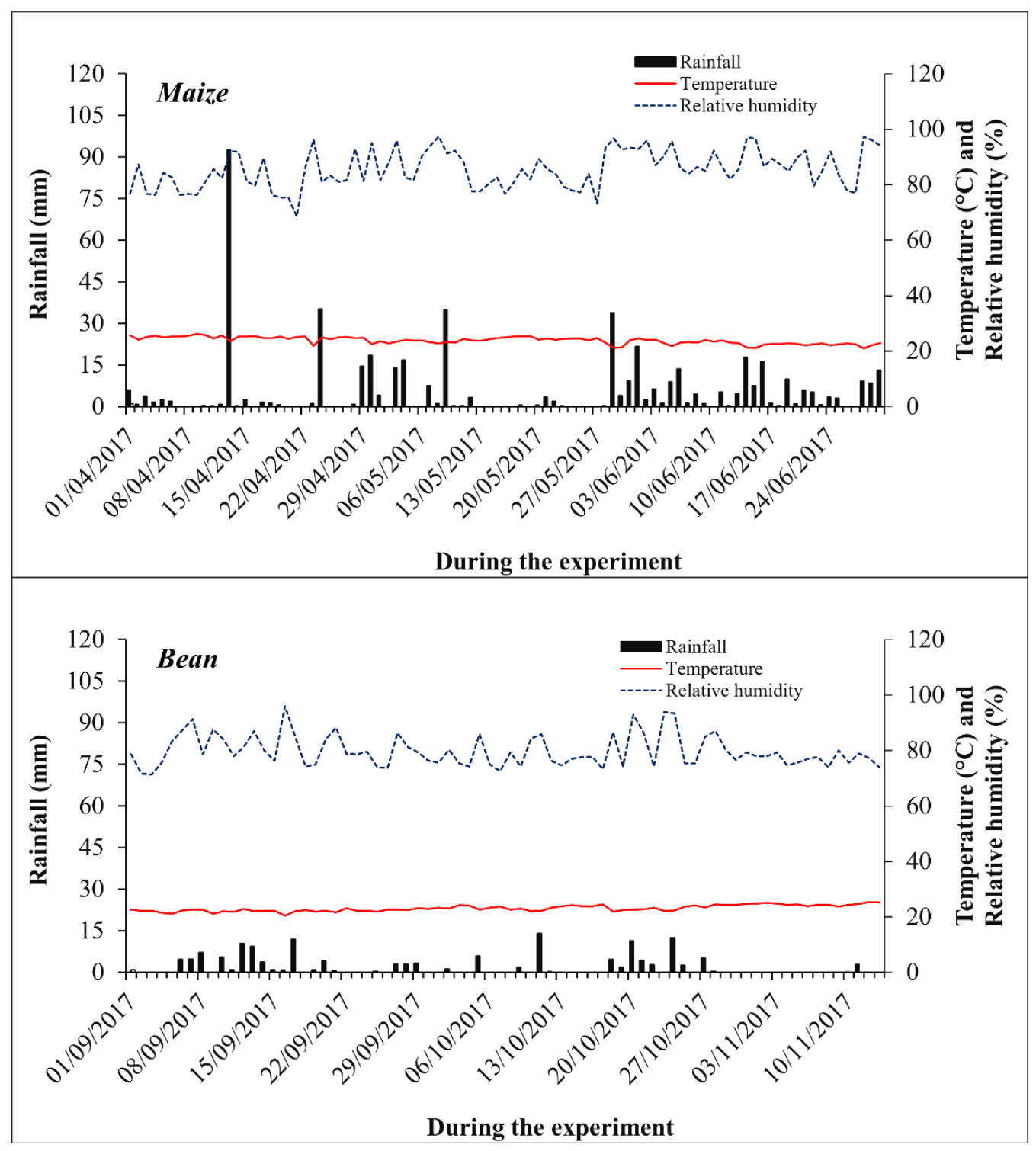

Figure 2. Precipitation $(\mathrm{mm})$, mean temperature $\left({ }^{\circ} \mathrm{C}\right)$ and relative air humidity $(\%)$ in the period of conduction of the experiment, between April and June (maize), and September and November (bean) of 2017. Data collected at the Meteorological Station of the Center for Agrarian Sciences, Federal University of Paraíba, Areia-PB (Source: Instituto Nacional de Meteorologia - INMET)

The experiment was set up in a randomized complete block design, in a 5 x 2 factorial scheme, totaling 10 treatments, five $\mathrm{K}$ doses $\left(0 \mathrm{~kg} \mathrm{ha}^{-1}, 50 \mathrm{~kg} \mathrm{ha}^{-1}, 100 \mathrm{~kg} \mathrm{ha}^{-1}, 150 \mathrm{~kg} \mathrm{ha}^{-1}\right.$ and $200 \mathrm{~kg} \mathrm{ha}^{-1}$ ) and two fertilization periods (seeding and V5 stadium) in maize plants. $\mathrm{K}$ chloride was used as the source of $\mathrm{K}$. These treatments were similar for bean plants, in which the residual effect of $\mathrm{K}$ fertilization under growth in succession with maize crop was evaluated. All evaluations were carried out in five plants randomly selected in each plot, in the three central lines. 


\section{NI Macrothink}

For maize, the cultivation AG 1051 (double hybrid) was used: which has the following characteristics: open architecture foliar, semi-precocious cycle, yellow toothed grains, average height of the plant $2.20 \mathrm{~m}$, height of insertion of the spike considered high $1.12 \mathrm{~m}$, and its production can be intended for grain production, silage, green maize. For the Beans, the cultivation BRS was used, it presents a semi-precocious cycle, high productive potential, lodging tolerance and resistance to anthracnose and fusarium wilt.

Initially, the experiment received fertilization of 30 and $60 \mathrm{~kg} \mathrm{ha}^{-1}$ de $\mathrm{N} \mathrm{e}_{2} \mathrm{O}_{5}$ at the planting (in the form of urea and simple superphosphate). These plots presented an area of $4,5 \mathrm{~m}^{2}$. Maize sowing was done in lines with 4 furrows/plot, with spacing between lines of $50 \mathrm{~cm}$ and 3 seeds per linear meter ${ }^{-1}$, obtaining an estimated population of 60,000 plants per hectare ${ }^{-1}$. Bean sowing was carried out 60 days after maize harvest, with 30 seeds that were planted in each 3 meter line, spaced $50 \mathrm{~cm}$ apart, with a population of approximately 200,000 plants per hectare $^{-1}$. The chemical characteristics of the soil collected before planting the maize is shown in Table 1. For soil analysis, individual samples were collected in each experimental plot, and then combined to form a composite analysis. At the end of the experiment (after bean harvested), the $\mathrm{K}$ analysis was performed in all experimental plots, the mean values of which are shown in Table 2.

Table 1. Chemical attributes of soil in the experimental area before maize planting

\begin{tabular}{|c|c|c|c|c|c|c|c|c|c|c|}
\hline \multirow[b]{2}{*}{$\mathrm{pH}$ in $\mathrm{H}_{2} \mathrm{O}$} & $\mathrm{P}$ & $\mathrm{K}$ & $\mathrm{Na}$ & $\mathrm{H}+\mathrm{Al}$ & $\mathrm{Al}$ & $\mathrm{Ca}$ & $\mathrm{Mg}$ & BS & CEC & \multirow{2}{*}{$\frac{\mathrm{O} . \mathrm{M}}{\mathrm{g} \mathrm{kg}^{-1}}$} \\
\hline & \multicolumn{2}{|c|}{$\mathrm{mg} \mathrm{dm}{ }^{3}$} & \multicolumn{7}{|c|}{ cmolc $\mathrm{dm}^{3}$} & \\
\hline 5.4 & 26.43 & 43.67 & 0.23 & 2.21 & 0.05 & 0.85 & 0.23 & 1.42 & 3.63 & 22.45 \\
\hline
\end{tabular}

BS: base sum; CEC: cation exchange capacity; O.M: organic matter.

Table 2. Chemical analysis of $\mathrm{K}$ at the soil of experimental area after bean planting

\begin{tabular}{lc}
\hline $\begin{array}{c}\text { Treatments } \\
\left(\mathrm{kg} \mathrm{ha}^{-1}\right)\end{array}$ & $\begin{array}{c}\mathrm{K} \\
\left(\mathrm{mg} / \mathrm{dm}^{3}\right)\end{array}$ \\
\hline Seeding & \\
\hline 0 & 42.35 \\
50 & 30.77 \\
100 & 28.01 \\
150 & 38.15 \\
200 & 32.30 \\
\hline V5 stadium & \\
\hline 0 & 25.41 \\
50 & 22.86 \\
100 & 24.72 \\
150 & 27.46 \\
200 & 30.03 \\
\hline
\end{tabular}

The analyzes of growth, gas exchange and productivity were carried out in maize plants. For the bean plants, growth analyzes were performed. 


\subsection{Growth}

In maize plants, the height was determined through a metric scale graduated in centimeters, that was measured from the neck to the apex of the last open leaf; the diameter of the stem, using a pachymeter, with measurements that were taken above $2 \mathrm{~cm}$ from the soil; and the number of leaves, evaluating the photosynthetically active leaves. The evaluations were made at 60 and 90 days after planting (DAP). For the beans, the height of plants, stem diameter, number of nodes and number of leaves were evaluated, and they were performed at 20 and 40 days after planting (DAP).

\subsection{Gas Exchange}

The gas exchange evaluations were carried out in maize plants, in which the rate of photosynthesis $(\mathrm{A})\left(\mu \mathrm{mol} \mathrm{m} \mathrm{s}^{-1}\right)$, internal $\mathrm{CO}_{2}$ concentration $(\mathrm{Ci})\left(\mu \mathrm{mol} \mathrm{mol}{ }^{-1}\right)$, transpiration (E) $\left(\mathrm{mmol} \mathrm{m} \mathrm{m}^{-2} \mathrm{~s}^{-1}\right)$, stomatal conductance $(\mathrm{gs})\left(\mathrm{mol} \mathrm{m} \mathrm{m}^{-2} \mathrm{~s}^{-1}\right)$, instantaneous water use efficiency (WUE - A/E), with the ratio of photosynthesis and transpiration rate $\left[\left(\mu \mathrm{mol} \mathrm{m} \mathrm{m}^{-2} \mathrm{~s}^{-1}\right)\right.$ / $\left.\left(\mathrm{mmol} \mathrm{m} \mathrm{m}^{-2} \mathrm{~s}^{-1}\right)\right]$, intrinsic water use efficiency (iWUE - $\left.\mathrm{A} / \mathrm{gs}\right)$, calculated by the ratio between the photosynthetic rate and the stomatal conductance $\left[\left(\mu \mathrm{mol} \mathrm{m} \mathrm{m}^{-2} \mathrm{~s}^{-1}\right) /\left(\mathrm{mol} \mathrm{m}^{-2} \mathrm{~s}^{-1}\right)\right]$ and the instantaneous carboxylation efficiency (ICE - A/Ci) $\left[\left(\mu \mathrm{mol} \mathrm{m} \mathrm{s}^{-1}\right) /\left(\mu \mathrm{mol} \mathrm{mol}{ }^{-1}\right)\right]$ from the relation between the photosynthetic rate and the internal $\mathrm{CO}_{2}$ concentration. The readings were performed on healthy leaves and completely expanded, located in the middle third of the plants. A portable infrared radiation photosynthesis analyzer was used under maximum natural light conditions (IRGA) (model Li-6400XT, LI-COR). The evaluations were carried out in the period between 09:30 and 11:00 hours, 75 days after planting (DAP).

\subsection{Productivity}

For the evaluation of the primary productivity components, five random spikes of each plot were used: ear length, ear diameter, kernels rows number, number of kernels per row, kernel weight and kernel moisture content.

\subsection{Data Analysis}

For the statistical analysis of the data, we performed the analysis of variance, according to the design adopted. Subsequently, the data were submitted to regression analysis, with curve fitting, according to the parameters evaluated (Soares et al., 2016).

\section{Results and Discussion}

\subsection{Growth-Maize}

$\mathrm{K}$ fertilization influenced the growth of maize plants during the two fertilization periods (seeding and V5 stadium) at 45 and 75 days after planting (DAP).

In relation to plant height, there were significant differences with quadratic effect for the $\mathrm{K}$ doses in the two fertilization periods (Figure 3-A and B). The highest values were recorded at dose $150 \mathrm{~kg}$ of $\mathrm{K} \mathrm{ha}^{-1}$, with $57.6 \mathrm{~cm}$ at 45 DAP and $143.1 \mathrm{~cm}$ at 75 DAP. In the two evaluation periods the dose of $150 \mathrm{~kg}$ of $\mathrm{K} \mathrm{ha}^{-1}$ applied at the $\mathrm{V} 5$ stadium provided higher values for maize plant height, and the lowest values were recorded for the control $\left(0 \mathrm{~kg}\right.$ of $\left.\mathrm{K} \mathrm{ha}^{-1}\right)$. Kalpana and 


\section{Macrothink

Krishnarajan (2002) and Petter et al. (2016) observed a significant influence of the application times of $\mathrm{K}$ at maize plant height, corroborating with the results of this study. However, Rabêlo et al. (2013) did not verify differences in height of the plants submitted to the potassic doses applied at different fertilization periods. These distinct results may have occurred due to the different soil and climatic conditions found in each region studied.

The diameter of the stem of maize plants responded positively to $\mathrm{K}$ doses, mainly at 75 DAP (Figure 3-C and D). The dose of $150 \mathrm{~kg}$ of $\mathrm{K} \mathrm{ha}^{-1}$ in the V5 stadium provided the highest mean values in the two evaluation periods, with $2.28 \mathrm{~cm}$ at $45 \mathrm{DAP}$ and $2.69 \mathrm{~cm}$ at $75 \mathrm{DAP}$ (Figure 3-C and D). The dose of $150 \mathrm{~kg}$ of $\mathrm{K} \mathrm{ha}^{-1}$ had a positive influence on the diameter of the stem in the two fertilization periods, when it was verified that the K use in the V5 stadium had higher values, with an increase of 31.58 and $20.5 \%$ in the control $\left(0 \mathrm{~kg}\right.$ of $\left.\mathrm{K} \mathrm{ha}^{-1}\right)$ at 45 and 75 DAP, respectively (Figure 3-C and D) Andreotti et al. (2001) also observed a larger diameter of the stem with the increase of the doses of $\mathrm{K}$. This increase in stem diameter has fundamental importance for the development and physiology of plants, because the stem is a structure determined to the storage of soluble solids, that are used mainly in the formation of grains through the reserves, and it doesn 't have only having the function of sustain the leaves and inflorescences of plants (Carmo et al., 2012).

The increase of $\mathrm{K}$ doses in the two seasons of fertilization, provided a greater number of photosynthetically active leaves in maize plants (Figure 3-E and F). Compared with fertilization at seeding, in the V5 stadium at 45 and 75 DAP, the highest mean values were recorded, with 6.3 and 8.8 leaves plants $^{-1}$, respectively (Figure 3-E and F). At 75 DAP, there was a greater change in the values in the V5 stadium, ranging from 6.5 leaves in the control $\left(0 \mathrm{~kg} \mathrm{ha}^{-1}\right)$ to 8.8 leaves in the dose of $150 \mathrm{~kg}$ of $\mathrm{K} \mathrm{ha}^{-1}$ (Figure 3-E and F). For a greater number of leaves, $\mathrm{K}$ fertilization is of fundamental importance for the metabolism of plants, aiding in the physiological aspects of cell growth and division, increasing the distance between nodes and consequently the number of leaves (Kerbauy, 2012). 

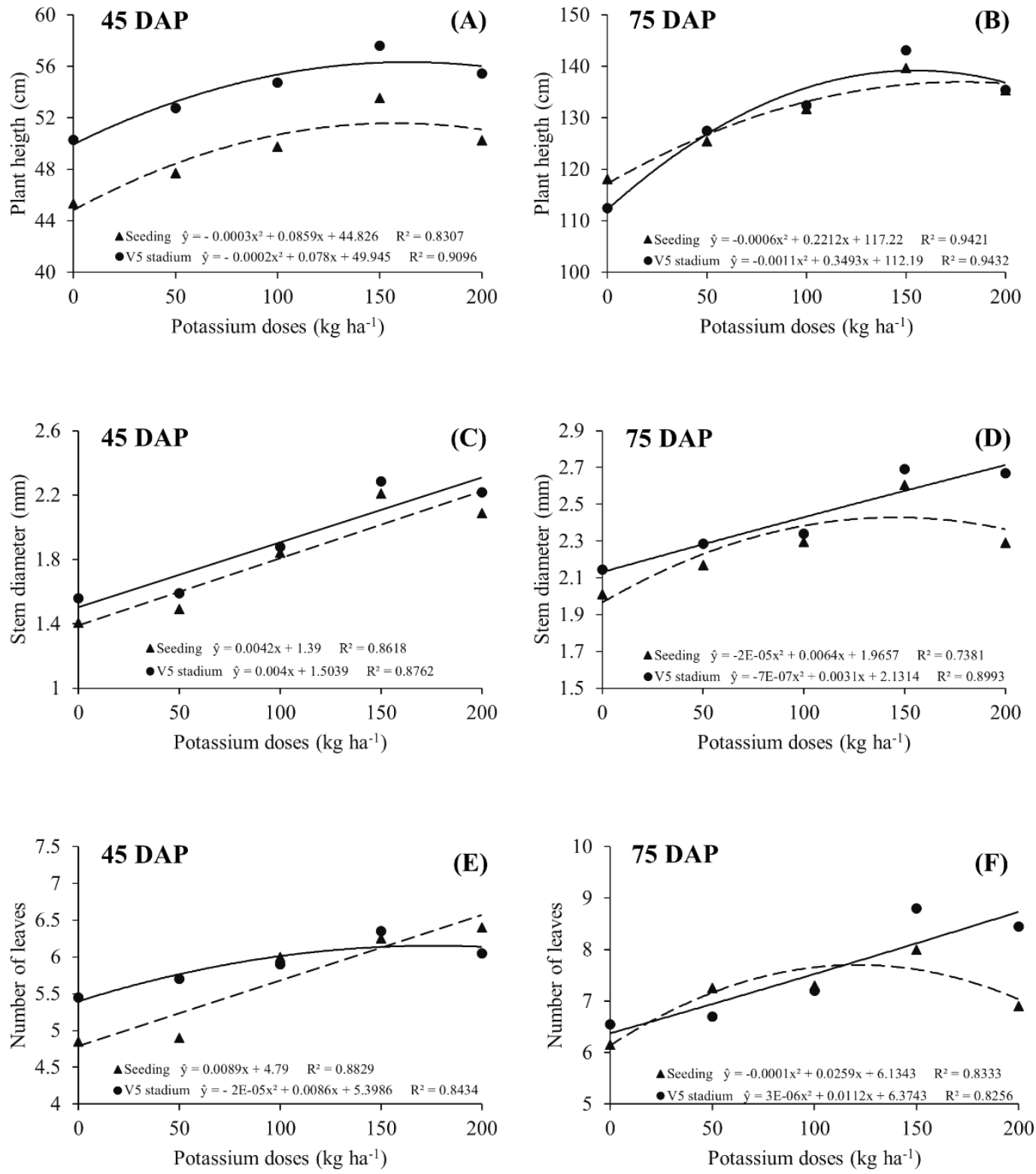

Figure 3. Plant height (A and B), stem diameter (C and D) and number of leaves (E and $F)$ in maize plants submitted to increasing $\mathrm{K}$ doses in two fertilization periods (seeding and V5 stadium) at 45 and 75 DAP

\subsection{Gas exchange - Maize}

The mean values of maize gas exchange responses in relation to the effects of $\mathrm{K}$ doses for the gas exchange results are shown in Figure 4. From the results of the analysis of variance, K fertilization in the two application periods significantly affected the photosynthesis rate, internal $\mathrm{CO}_{2}$ concentration, transpiration, stomatal conductance, instant water use efficiency, intrinsic water use efficiency, and the instantaneous efficiency of carboxylation (Figure 4).

The photosynthetic rate $(\mathrm{A})$ of maize plants as a function of $\mathrm{K}$ doses presented an increasing 
quadratic responses in the two seasons of fertilization (seeding and V5 stadium), in which the values ranged from 11.09 to $13.51 \mu \mathrm{mol} \mathrm{m} \mathrm{m}^{-2} \mathrm{~s}^{-1}$ in fertilization at seeding and from 11.48 to $15.85 \mu \mathrm{mol} \mathrm{m} \mathrm{m}^{-2}$ in the V5 stadium (Figure 4-A). The highest values were recorded in the dose of $150 \mathrm{~kg}$ of $\mathrm{K} \mathrm{ha}^{-1}$ in the two seasons of fertilization, however, the application of $\mathrm{K}$ in the V5 stadium of the plant provided higher values (Figure 4-A). The factor of the highest value of A was recorded in the dose of $150 \mathrm{~kg}$ of $\mathrm{K} \mathrm{ha}^{-1}$ in the two seasons of fertilization, may be related to the ideal amount of $\mathrm{K}$ that the maize plants need, and as the plant nutrition influences in the photosynthetic process, such dose promoted the highest values for this variable. According to Larcher (2006), high rates of photosynthesis can be recorded through fertilization.

The internal $\mathrm{CO}_{2}$ concentration $(\mathrm{Ci})$ presented a linear response decreasing to the effect of $\mathrm{K}$ doses in the two fertilization periods (Figure 4-B). The values at the time of fertilization at seeding provided the highest values, ranging from 62.38 to $91.15 \mu \mathrm{mol} \mathrm{mol}^{-1}$, with the highest values observed in the control $\left(0 \mathrm{~kg}\right.$ of $\left.\mathrm{K} \mathrm{ha}^{-1}\right)$ (Figure 4-B). At the time of fertilization at V5 stadium, mean values ranged from 58.63 to $77.39 \mu \mathrm{mol} \mathrm{mol}^{-1}$, in which the control $(0 \mathrm{~kg}$ of K $\mathrm{ha}^{-1}$ ) had higher values (Figure 4-B). This increase of $\mathrm{Ci}$ in the control indicates that CO 2 is not being used in the synthesis of sugars during the photosynthetic process, for example, a lower photosynthesis rate, and that there may be a non-stomatal factor influence in this case, leading to a higher accumulation of $\mathrm{Ci}$ in the leaves (Freire et al., 2014).

The results for transpiration (E) followed the same tendency of the photosynthesis rate, presenting a quadratic response to the effect of $\mathrm{K}$ doses in the two fertilization periods (Figure 4-C). At the time of fertilization at seeding the values ranged from 3.75 to $5.00 \mathrm{mmol}$ $\mathrm{m}^{-2} \mathrm{~s}^{-1}$, with the highest averages recorded at the dose of $150 \mathrm{~kg}$ of K ha ${ }^{-1}$ (Figure 4-C). In the fertilization carried out in the V5 stadium the plants presented higher values than the seeding season, with values ranging from 4.07 to $5.60 \mathrm{mmol} \mathrm{m}^{-2} \mathrm{~s}^{-1}$, where the dose of $150 \mathrm{~kg}$ of $\mathrm{K}$ $\mathrm{ha}^{-1}$ was most effective (Figure 4-C). This increase in the rate of transpiration at the dose of $150 \mathrm{~kg}$ of $\mathrm{K} \mathrm{ha}^{-1}$ at fertilization times causes an increase in the water flow in the xylem and the concentration of cytokinin in the roots, and it is an important factor for delaying leaf senescence, corroborating with the present study (Soares et al., 2013).

The stomatal conductance (gs) showed a quadratic response between the doses in the two seasons of fertilization (Figure 4-D). In fertilization at seeding, the dose of $100 \mathrm{~kg}$ of K ha ${ }^{-1}$ presented the highest values, ranging from 0.2178 to $0.3108 \mathrm{~mol} \mathrm{~m}^{-2} \mathrm{~s}^{-1}$ (Figure 4-D). At the time of fertilization in the V5 stadium the plants had the highest values, in which the dose of $150 \mathrm{~kg}$ of $\mathrm{K} \mathrm{ha}^{-1}$ gave the best results, with rates ranging from 0.2170 to $0.3555 \mathrm{~mol} \mathrm{~m}^{-2} \mathrm{~s}^{-1}$ (Figure 4-D). This response of the plants may be directly related to the lower stomatal opening in the lowest $\mathrm{K}$ doses, in order to avoid damage in the water system by the vegetable. $\mathrm{K}$ is involved in protoplasmic processes and photosynthesis, directly influencing the regulation of stomatal opening (Silva et al., 2013).

The instantaneous water use efficiency (WUE) values showed a quadratic response to the effect of increasing doses of $\mathrm{K}$ in the two fertilization periods (Figure 4-E). Comparing the seasons of fertilization, the highest values were recorded in fertilization at seeding at the dose 
of $150 \mathrm{~kg}$ of $\mathrm{K} \mathrm{ha}^{-1}$, with a variation of 2.44 and $3.36\left[\left(\mu \mathrm{mol} \mathrm{m}^{-2} \mathrm{~s}^{-1}\right) /\left(\mathrm{mmol} \mathrm{m}^{-2} \mathrm{~s}^{-1}\right)\right]$ (Figure 4-E). For V5 fertilization, the dose of $150 \mathrm{~kg}$ of $\mathrm{K} \mathrm{ha}^{-1}$ also provided the highest values, ranging from 2.59 to $3.25\left[\left(\mu \mathrm{mol} \mathrm{m} \mathrm{m}^{-2}\right) /\left(\mathrm{mmol} \mathrm{m}^{-2} \mathrm{~s}^{-1}\right)\right]$ (Figure 4-E). The increase made by the United States at the dose of $150 \mathrm{~kg}$ of $\mathrm{K} \mathrm{ha}^{-1}$ in fertilization at seeding and in V5 stadium of the plants may be related to the other variables of gas exchanges, in which the dose provided the highest values. Such a parameter is calculated by the ratio between the photosynthesis and transpiration rates $(\mathrm{A} / \mathrm{E})$, where the measured values involve the amount of carbon gained by the plant per unit of water that is lost (Jaimez et al., 2005).

For the intrinsic water use efficiency (iWUE), there was a quadratic effect of increasing doses of $\mathrm{K}$ at fertilization times (Figure 4-F). At the time of fertilization at seeding the values ranged from 42.67 to $59.56\left[\left(\mu \mathrm{mol} \mathrm{m} \mathrm{s}^{-1}\right) /\left(\mathrm{mol} \mathrm{m}^{-2} \mathrm{~s}^{-1}\right)\right]$, with the dose of $150 \mathrm{~kg}$ of $\mathrm{K} \mathrm{ha}{ }^{-1}$ registering the highest rates (Figure 4-F). At the time of fertilization in the V5 stadium of the plants, the values were higher than the fertilization at seeding, with a variation from 46.81 to $60.71\left[\left(\mu \mathrm{mol} \mathrm{m} \mathrm{s}^{-1}\right) /\left(\mathrm{mol} \mathrm{m}^{-2} \mathrm{~s}^{-1}\right)\right]$, in which the dose of $150 \mathrm{~kg}^{-1} \mathrm{~K} \mathrm{ha}^{-1}$ provided the best results. These higher values that were elaborated by the United States, in the dose of $150 \mathrm{~kg}$ of $\mathrm{K} \mathrm{ha}^{-1}$ in the two seasons of fertilization, becomes an indicative that with the increase of the liquid photosynthesis the stomatal conductance also increased, however, the reduction of the gs was greater than the reduction of A, supporting the occurrence of stomatal limitation (Bertolli et al., 2015).

The instantaneous carboxylation efficiency (ICE) showed differences in the different increasing doses of $\mathrm{K}$, with linear effect at the time of fertilization at seeding and quadratic effect at fertilization at V5 stadium (Figure 4-G). The highest values were recorded when doses of $\mathrm{K}$ were applied at the V5 stadium, with values ranging from 0.2211 to 0.2939 [ $(\mu \mathrm{mol}$ $\left.\left.\mathrm{m}^{-2} \mathrm{~s}^{-1}\right) /\left(\mu \mathrm{mol} \mathrm{mol}{ }^{-1}\right)\right]$, in which the dose of $150 \mathrm{~kg}$ of $\mathrm{K} \mathrm{ha}^{-1}$ presented the highest values found (Figure $4-\mathrm{G})$. At the time of seeding the values ranged from 0.1578 to 0.2400 [ $(\mu \mathrm{mol}$ $\left.\left.\mathrm{m}^{-2} \mathrm{~s}^{-1}\right) /\left(\mu \mathrm{mol} \mathrm{mol}{ }^{-1}\right)\right]$, in which the dose of $150 \mathrm{~kg}$ of K ha ${ }^{-1}$ presented a higher rate than the others (Figure 4-G). The higher values of ICE recorded at the dose of $150 \mathrm{~kg}^{-1} \mathrm{~K} \mathrm{ha}^{-1}$ are a reflection of the high photosynthesis rate in relation to the decrease in the internal concentration of $\mathrm{CO}_{2}$ in the plants, because in this way if the $\mathrm{Ci}$ decreases there may be an increase in the consumption of $\mathrm{CO} 2$ in the chloroplast due to the highest photosynthetic activity, and thus the $\mathrm{A} / \mathrm{Ci}$ ratio has high values, as it was observed in the present study. 

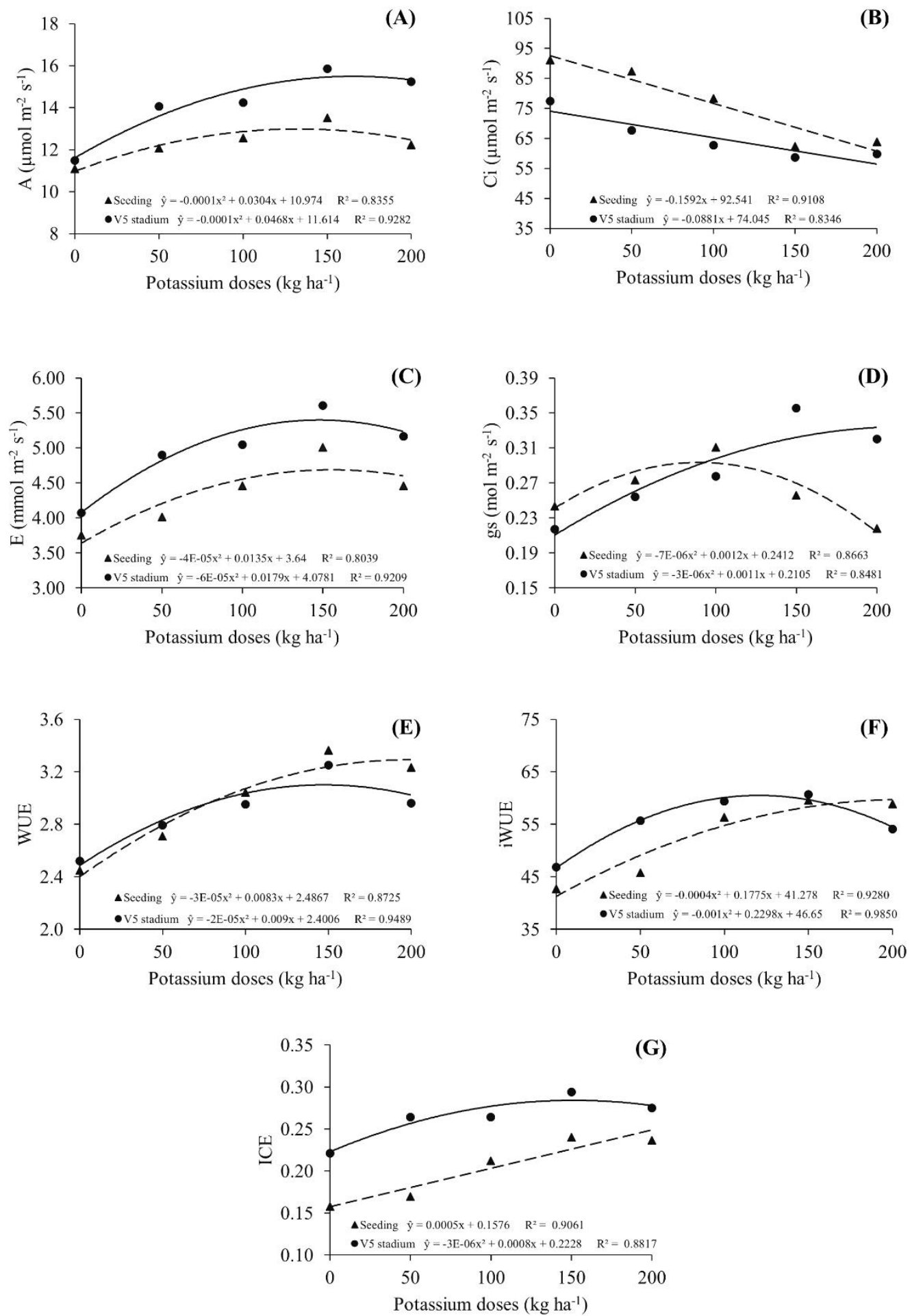

Figure 4. Photosynthetic rate (A), internal $\mathrm{CO}_{2}$ concentration (B), transpiration $(\mathrm{C})$, stomatal conductance (D), instantaneous water use efficiency (E), intrinsic water use efficiency (F) and instantaneous carboxylation efficiency $(\mathrm{G})$ in maize plants submitted to increasing $\mathrm{K}$ doses in two fertilization periods (seeding and V5 stadium) 


\subsection{Productivity - Maize}

The mean values of the productivity indexes of maize plants as a function of increasing doses of $\mathrm{K}$ at two application times are presented in Figure 5. According to the analysis of variance, the $\mathrm{K}$ doses in the two fertilization periods (seeding and V5 stadium) significantly affected the length spike diameter, number of rows of grains, number of grains per row, grain weight and kernel moisture content (Figure 5). Petter et al. (2016) in their study, found similar results, in which $\mathrm{K}$ doses influenced all productivity variables except for the length of spikes.

The ear length values showed a quadratic effect in relation to the $\mathrm{K}$ doses at the different times of application (seeding and V5 stadium) (Figure 5-A). Fertilization in the V5 stadium gave the highest values, ranging from 13.74 to $18.65 \mathrm{~cm}$, at the dose of $150 \mathrm{~kg}$ of K ha ${ }^{-1}$ (Figure 5-A). At seeding the values ranged from 13.71 to $16.25 \mathrm{~cm}$, where the highest value was recorded at the dose of $150 \mathrm{~kg}$ of $\mathrm{K} \mathrm{ha}^{-1}$ (Figure 5-A). For the ear diameter, there was a quadratic response in relation to the increasing doses of $\mathrm{K}$ in the two fertilization periods (seeding and V5 stadium) (Figure 5-B). In seeding the values ranged from 42.30 to $50.93 \mathrm{~mm}$, in which the dose of $150 \mathrm{~kg}$ of $\mathrm{K} \mathrm{ha}^{-1}$ was more effective than the others. In the V5 stadium, the highest values were recorded in maize plants, at a dose of $150 \mathrm{~kg} \mathrm{de} \mathrm{K} \mathrm{ha}^{-1}$, with a variation of 45.91 to $54.64 \mathrm{~mm}$ (Figure 5-B).

In their study, Cavallet et al. (2000) recorded mean values for ear length between 13.6 and $14.4 \mathrm{~cm}$, presenting values similar to the present study. But for Lopes et al. (2007), ear length is not essential for production when the area exhibits a small number of spikes.

The kernels rows number as a function of different $\mathrm{K}$ doses presented a quadratic response in the two seasons of fertilization (seeding and V5 stadium) (Figure 5-C). The highest values were recorded with the fertilization in V5 stadium, in the dose of $150 \mathrm{~kg}$ of K ha ${ }^{-1}$, with variation of 11.59 to 15.40 kernels rows (Figure 5-C). In fertilization at seeding the values varied from 11.70 to 14.45 kernels rows, in which the dose of $150 \mathrm{~kg}$ of K ha ${ }^{-1}$ was higher (Figure 5-C). The number of kernels per row presented quadratic responses as a function of the different doses of $\mathrm{K}$ in two times of application (seeding and V5 stadium) (Figure 5-D). The seeding fertilization presented values ranging from 25.31 to 28.81 kernels per row, in which the dose of $100 \mathrm{~kg}$ of $\mathrm{K} \mathrm{ha}^{-1}$ registered the highest value (Figure 5-D). On the other hand, fertilization in the V5 stadium presented higher values ranging from 25.52 to 29.41 kernels per row, in which the dose of $200 \mathrm{~kg}$ of $\mathrm{K} \mathrm{ha}^{-1}$ provided the highest grain yield per row (Figure 5-D).

For kernel weight as a function of increasing $\mathrm{K}$ doses, there was a quadratic effect for seeding and linear effect for fertilization in the V5 stadium of the plants (Figure 5-E). Fertilization at seeding presented the highest values for this variable, with values between 124.03 and 162.59 $\mathrm{g}$, in which the dose of $100 \mathrm{~kg}$ of $\mathrm{K} \mathrm{ha}^{-1}$ was responsible for providing the highest kernel weight in maize plants (Figure 5-E). In the V5 fertilization the values ranged from 122.43 to $157.24 \mathrm{~g}$ with the highest values recorded at the dose of $150 \mathrm{~kg}$ of $\mathrm{K} \mathrm{ha}^{-1}$ (Figure 5-E). The kernel moisture content $(\%)$ at the time of harvest varied significantly as a function of the different doses of $\mathrm{K}$, presenting a quadratic effect in the two seasons of fertilization (seeding and V5 stadium) (Figure 5-F). At the time of fertilization at seeding the average values 


\section{Macrothink}

ranged from 22.12 to $24.53 \%$, with the highest values recorded at the dose of $100 \mathrm{~kg}$ of $\mathrm{K}$ $\mathrm{ha}^{-1}$ (Figure 5-F). Already the fertilization of the plants in V5 stadium provided higher values, ranging from 22.95 to $24.60 \%$, in which at the dose of $100 \mathrm{~kg}$ of $\mathrm{K} \mathrm{ha}^{-1}$ the kernel moisture was higher (Figure 5-F).

However, Deparis et al. (2007) in their study did not find a significant effect of the K doses (3 $\mathrm{kg} \mathrm{ha}^{-1} ; 7,5 \mathrm{~kg} \mathrm{ha}^{-1} ; 15 \mathrm{~kg} \mathrm{ha}^{-1} ; 30 \mathrm{~kg} \mathrm{ha}^{-1} ; 45 \mathrm{~kg} \mathrm{ha}^{-1} ; 52,5 \mathrm{~kg} \mathrm{ha}^{-1}$; and $57 \mathrm{~kg} \mathrm{ha}^{-1}$ of $\mathrm{K}$ ) on the productivity variables mentioned above, which may have occurred due to the use of lower doses of $\mathrm{K}$, differently from the present study, in which higher doses $\left(100 \mathrm{~kg} \mathrm{ha}^{-1} ; 150 \mathrm{~kg} \mathrm{ha}^{-1}\right.$; and $200 \mathrm{~kg} \mathrm{ha}^{-1}$ ) provided the highest productivity indexes in plants of maize in the two seasons of fertilization. This fact possibly happened due to the fact that $\mathrm{K}$ directly influences the cell growth, with the enzymatic activation in the transport of the Nitrogen, causing the formation of the vegetal tissues (Taiz et al., 2017). Büll (1993) observed that K influences the development of the crop, as well as the number of grains per spike and kernel weight. Wendling et al. (2008), found that maize under no-tillage did not significantly respond to K fertilization, in most sites and crops, in experiments conducted in Paraguay. 

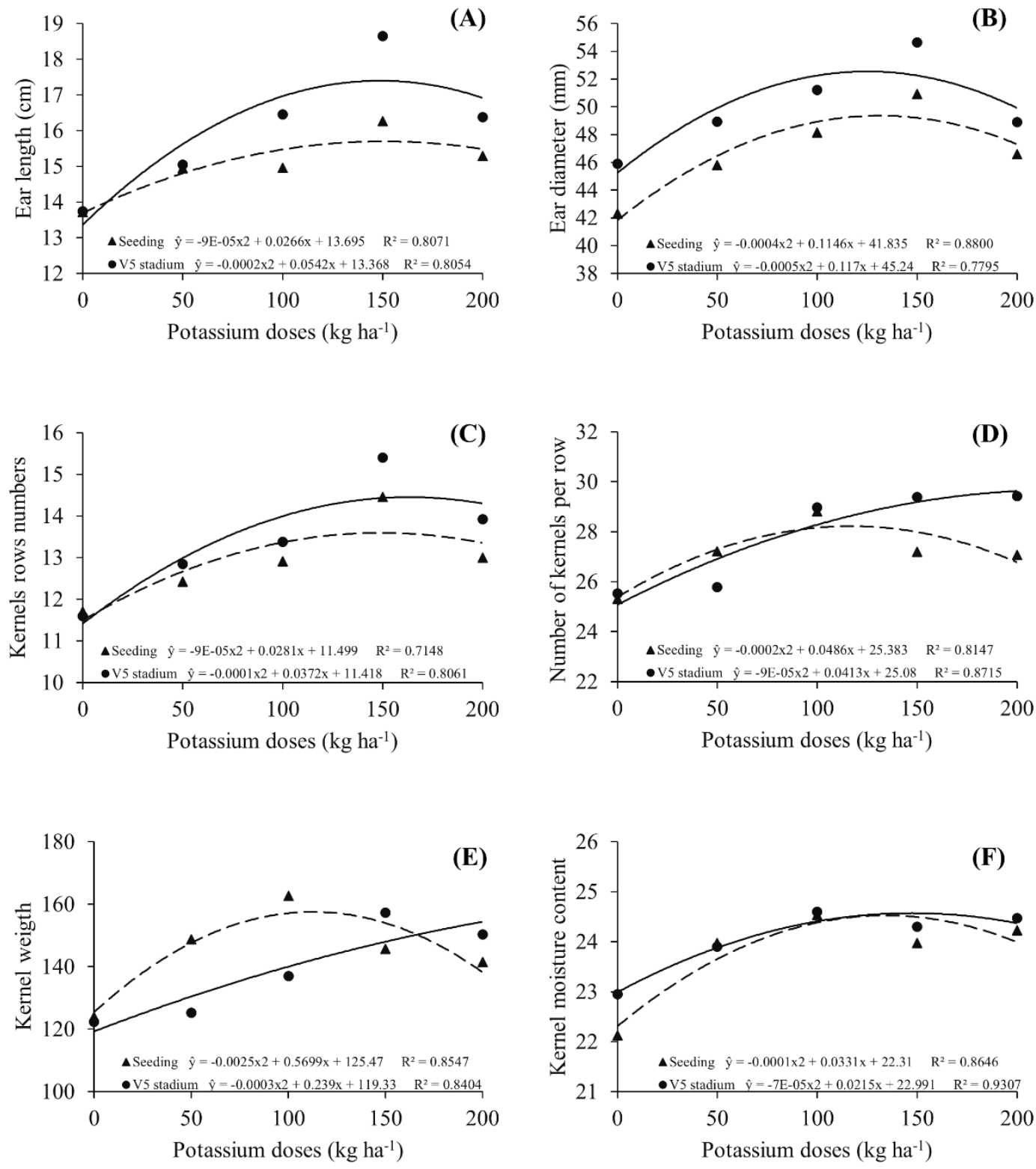

Figure 5. Ear length (A), ear diameter (B), kernels rows number (C), number of kernels per row (D), kernel weight (E) and kernel moisture content (\%) (F) in maize plants submitted to increasing $\mathrm{K}$ doses in two fertilization periods (seeding and V5 stadium)

\subsection{Growth - Bean}

According to the growth analysis of bean plants cultivated in the same area as maize, $\mathrm{K}$ fertilization was significantly influenced by plant height, stem diameter, number of nodes and number of leaves in the two seasons of fertilization (seeding and V5 stadium) 20 and 40 days after planting (DAP) (Figure 6). These results do not corroborate with the study by Melo et al. (2005), in which the beans hardly respond to K fertilization.

The height of bean plants as a function of the $\mathrm{K}$ doses showed quadratic responses in the two 
fertilization periods (Figure 6-A and B). In the V5 fertilization, the highest values were recorded at the dose of $200 \mathrm{~kg}$ of $\mathrm{K} \mathrm{ha}^{-1}$, ranging from 24.65 to $29.20 \mathrm{~cm}$ at $20 \mathrm{DAP}$, and from 29.90 to $33.25 \mathrm{~cm}$ at 40 DAP (Figure 6-A and B). In fertilization at seeding the dose of $200 \mathrm{~kg}$ of $\mathrm{K} \mathrm{ha}^{-1}$ provided higher values for plant height, ranging from 24.3 to $28.4 \mathrm{~cm}$ at 20 DAP, and from 27.15 to 32.45 at 40 DAP (Figure 6-A and B). Comparing the two seasons of fertilization, it was verified that the fertilization in V5 stadium was superior for the height of plants (Figure 6-A and B). Souza et al. (2013) evaluating the effect of increasing potassic doses on black string beans, found a significant effect on plant height as a function of the doses used. The residual effect of the $\mathrm{K}$ doses is directly related to the growth of the bean plants, with the best development recorded in the highest $\mathrm{K}$ doses.

For stem diameter in bean plants as a function of increasing $\mathrm{K}$ doses, there was a quadratic response for seeding at $20 \mathrm{DAP}$ and linear at $40 \mathrm{DAP}$, and for fertilization at V5 stadium there was linear effect at 20 DAP and quadratic at 40 DAP (Figure 6-C and D). At fertilization in seeding the dose of $150 \mathrm{~kg}$ of $\mathrm{K} \mathrm{ha}^{-1}$ presented the highest values at $20 \mathrm{DAP}$, ranging from 4.20 to $4.90 \mathrm{~mm}$, and at 40 DAP the dose of $200 \mathrm{~kg}$ of $\mathrm{K} \mathrm{ha}^{-1}$ presented higher values, ranging from 4.50 to $5.50 \mathrm{~mm}$ (Figure 6-C and D). In fertilization in V5 stadium, the dose of $200 \mathrm{~kg}^{\circ} \mathrm{K} \mathrm{ha}{ }^{-1}$ presented the highest values in the two evaluation periods, with values varying from 4.26 to $4.95 \mathrm{~mm}$ at $20 \mathrm{DAP}$ and 4.83 to $5.75 \mathrm{~mm}$ at $40 \mathrm{DAP}$ (Figure 6-C and D).

The diameter of the stem is of fundamental importance to evaluate the potential and development of agricultural species, thus, the plants that present larger stem diameters, consequently also provide higher productivity indexes, and it is less susceptible to tipping (Souza et al., 2006). Anyway, as for Sousa et al. (2013), increasing doses of K did not significantly influence stem diameter in bean plants.

In relation to the number of nodes in common bean plants under increasing doses of $\mathrm{K}$, it was observed that there was a quadratic effect on fertilization at seeding at 20 and 40 DAP and linear effect on fertilization at V5 stadium at 20 DAP and quadratic at 40 DAP (Figure 6-E and F). In fertilization at seeding the values varied from 3.60 to 4.20 at 20 DAP, and from 4.30 to 5.45 at 40 DAP when the dose of $200 \mathrm{~kg}$ of $\mathrm{K} \mathrm{ha}^{-1}$ presented the highest values (Figure 6-E and F). In the V5 fertilization, the values in the two evaluation periods ranged from 3.25 to 4.20 at $20 \mathrm{DAP}$, and from 4.70 to 6.05 at $40 \mathrm{DAP}$, in which the dose of $200 \mathrm{~kg}$ of $\mathrm{K} \mathrm{ha}^{-1}$ presented better responses in both seasons of the evaluations (Figure 6-E and F).

The number of leaves of bean plants submitted to different potassic doses presented increasing linear responses in the different evaluation periods (20 and 40 DAP) and in the two fertilization periods (seeding and V5 stadium) (Figure 6-G and H). In fertilization at seeding the dose of $200 \mathrm{~kg}$ of $\mathrm{K} \mathrm{ha}^{-1}$ registered the highest values, which varied from 4.95 to 5.98 at $20 \mathrm{DAP}$, and from 7.10 to 9.55 at $40 \mathrm{DAP}$ (Figure 6-G and H). At the time of fertilization in V5 stadium the values varied from 4.65 to 6.03 at $20 \mathrm{DAP}$, and from 7.35 to 9.20 at $40 \mathrm{DAP}$, in which the dose of $200 \mathrm{~kg}$ of $\mathrm{K} \mathrm{ha}^{-1}$ was superior to the others (Figure 6-G and $\mathrm{H}$ ). This positive response of bean plants to residues of $\mathrm{K}$ fertilization in intercropping with maize can be explained by the fact that higher doses of $\mathrm{K}$ meet the nutritional needs of the crop in a balanced way (Oliveira et al., 2009). 

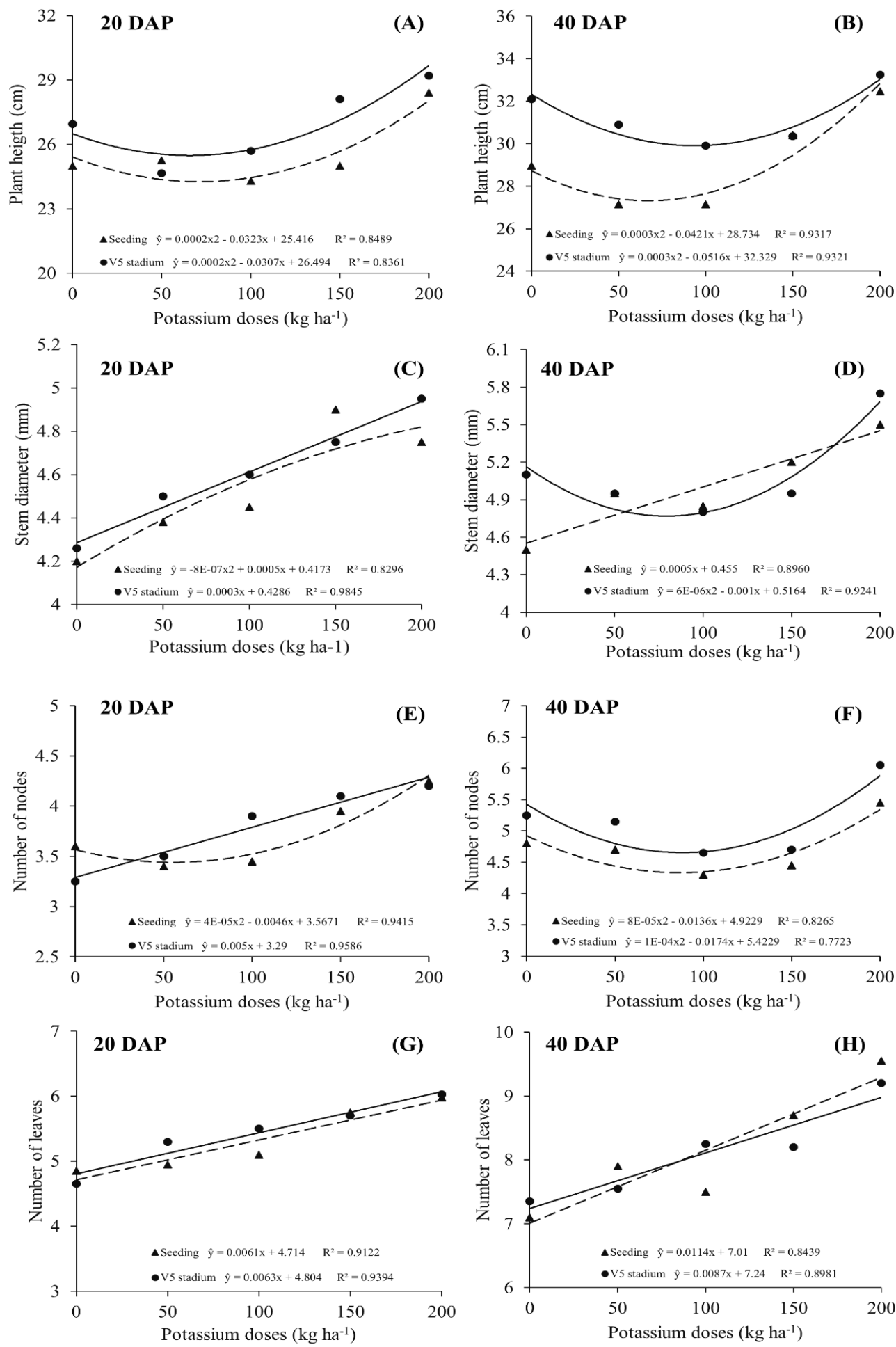

Figure 6. Plant height (A and B), stem diameter (C and D), number of nodes (E and F) and number of leaves $(\mathrm{G}$ and $\mathrm{H})$ in bean plants submitted to increasing $\mathrm{K}$ doses in two fertilization periods (seeding and V5 stadium) at 20 and 40 DAP 


\section{Conclusion}

There is an effect of $\mathrm{K}$ fertilization on growth, gas exchange and maize productivity in the two planting seasons, with fertilization in the V5 stadium, and it is the most appropriate for the crop;

The dose of $150 \mathrm{~kg} \mathrm{ha}^{-1}$ provided better development in maize plants during the two planting seasons (seeding and V5 stadium);

$\mathrm{K}$ fertilization at seeding and in V5 stadium promoted residual effect on bean growth, with the dose of $200 \mathrm{~kg} \mathrm{ha}^{-1}$ providing the best development of plants;

For the greater development of maize, it is recommended to use the dose of $150 \mathrm{~kg} \mathrm{ha}^{-1}$ at the V5 stadium of plants.

\section{References}

Andreotti, M., Rodrigues, J. D., Crusciol, C. A. C., Souza, E. C. A., \& Bull, L. T. (2001). Crescimento do milho em função da saturação por bases e da adubação potássica. Scientia Agrícola, 58(1), 145-150. https://doi.org/10.1590/S0103-90162001000100022

Benites, V. M., Carvalho, M. C. S., Resende, A. V., Polidoro, J. C., Bernadi, A. C. C., \& Oliveira, F. A. (2010). Potássio, cálcio e magnésio. In: L. I. Prochnow, V. Casarin, \& S. R. Stipp (Eds.), Boas práticas para uso eficiente de fertilizantes: nutrientes (pp. 137-191). Piracicaba: IPNI.

Bertolli, S. C., Souza, J., \& Souza, G. M. (2015). Caracterização fotossintética da espécie isohídrica Pata-de-Elefante em condições de deficiência hídrica. Revista Caatinga, 28(3), 196-205. https://doi.org/10.1590/1983-21252015v28n322rc

Büll, L. T. (1993). Nutrição mineral do milho. In L. T. Büll, \& Hcantarella, H. (Eds.), Cultura do milho: fatores que afetam a produtividade (pp. 63-145). Piracicaba: Potafos.

Carmo, M. S., Cruz, S. C. S., Souza, E. J., Campos, L. F. C., \& Machado, C. G. (2012). Doses e fontes de nitrôgenio no desenvolvimento e produtividade da cultura de milho doce (Zea mays convar. saccharata var. rugosa). Bioscience Journal, 28(1), 223-231.

Cavallet, L. E., Pessoa, A. C. S., Helmich, J. J., Helmich, P. R., \& Ost, C. F. (2000). Produtividade do milho em resposta à aplicação de nitrogênio e inoculação das sementes com Azospirillum spp. Revista Brasileira de Engenharia Agrícola e Ambiental, 4(1), 129-132. https://doi.org/10.1590/S1415-43662000000100024

Cavalli, E., \& Lange, A. (2018). Efeito residual do potássio no sistema de cultivo soja-milho safrinha no Cerrado Mato-Grossense. Cultura Agronômica, 27(2), 310-326.

Coelho, A. M. (2006). Nutrição e Adubação do Milho. Sete Lagoas: Embrapa Milho e Sorgo. p. 10.

Coelho, A. M., França, G. E., Pitta, G. V. E., Alves, V. M. C., \& Hernani, L. C. (2007). Cultivo do milho. (Sistemas de produção 1). Brasília: Embrapa CNPMS. s/p. 


\section{Macrothink}

Journal of Agricultural Studies

ISSN 2166-0379

2019, Vol. 7, No. 4

Deparis, G. A., Lana, M. C., \& Frandoloso, J. F. (2007). Espaçamento e adubação nitrogenada e potássica em cobertura na cultura do milho. Acta Scientiarum Agronomy, 29(4), 517-525. https://doi.org/10.4025/actasciagron.v29i4.414

Ernani, P. R., Almeida, J. A., \& Santos, F. C. (2007). Potássio. In R. F. Novais, V. V. H. Alvarez, N. F. Barros, R. L. F. Fontes, R. B. Cantarutti, \& J. C. L. Neves (Eds.), Fertilidade do solo (pp. 551-594). Viçosa: Sociedade Brasileira de Ciência do Solo.

Ferreira, E. V. O., Anghinoni, I., Andrighetti, M. H., Martins, A. P., \& Carvalho, P. C. F. (2011). Ciclagem e balanço de potássio e produtividade de soja na integração lavoura-pecuária sob semeadura direta. Revista Brasileira de Ciência do Solo, 35(1), 161-169. https://doi.org/10.1590/S0100-06832011000100015

Freire, J. L. O., Dias, T. J., Cavalcante, L. F., Fernandes, P. D., \& Lima Neto, A. J. (2014). Rendimento quântico e trocas gasosas em maracujazeiro amarelo sob salinidade hídrica, biofertilização e cobertura morta. Revista Ciência Agronômica, 45(1), 82-91.

https://doi.org/10.1590/S1806-66902014000100011

Jaimez, R. E., Rada, F., García-Núñez, C., \& Azócarb, A. (2005). Seasonal variations in leaf gas exchange of platain cv. 'Hartón' (Musa AAB) under different soil water conditions in a humid tropical region. Scientia Horticulturae, 104(1), 79-89.

https://doi.org/10.1016/j.scienta.2004.07.002

Kalpana, R., \& Krishnarajan J. (2002). Effect of dose and time of potassium application on yield and quality of baby corn. Agricultural Science Digest, 22(1), 59-60.

Kerbauy, G. B. (2012). Fisiologia vegetal. (2nd ed.). Rio de Janeiro: Guanabara Koogan. p. 431.

Larcher, W. (2006). Ecofisiologia vegetal. São Carlos: RIMA. p. 531.

Lopes, V. J., Lucio, A. D. C., Storck, L., Damo, H. P., Brum, B., \& Santos, V. J. (2007). Relações de causa e efeito em espigas de milho relacionadas aos tipos de híbridos. Ciência Rural, 37(6), 1536-1542. https://doi.org/10.1590/S0103-84782007000600005

Melo, F. B., Cardoso, M. J., \& Salviano, A. A. C. (2005). Fertilidade do solo e adubação. In F. B. Melo, M. J. Cardoso, \& A. A. Salviano (Eds.), Feijão-Caupi: avanços tecnológicos (pp. 228-242). Brasília: Embrapa Meio-Norte.

Oliveira, F., Cavalcante, L., Silva, I., Pereira, W., Oliveira, J., \& Costa Filho, J. (2009). Crescimento do milho adubado com nitrogênio e fósforo em um Latossolo Amarelo. Revista Brasileira de Ciências Agrárias, 4(3), 238-244. https://doi.org/10.5039/agraria.v4i3a1

Oliveira, I. P., Araujo, R. S., \& Dutra, L. G. (1996). Nutrição mineral e fixação biológica de nitrogênio. In R. S. Araújo, C. Rava, L. F. Stone, \& M. J. O. Zimmermann (Eds.), Cultura do feijoeiro comum no Brasil (pp. 169-221). Piracicaba: Potafos.

Parente, T. L., Lazarini, E., Caioni, S., De Souza, L. G. M., Pivetta, R. S., \& Bossolani, J. W. (2016). Potássio em cobertura no milho e efeito residual na soja em sucessão. Revista 
Agro@mbiente,10(3), 193-200. https://doi.org/10.18227/1982-8470ragro.v10i3.3258

Pavinato, P. S., Caretta, C. A., Girotto, E., \& Moreira, I. C. L. (2008). Nitrogênio e potássio em milho irrigado: análise técnica e econômica da fertilização. Ciência Rural, 38(2), 358-364. https://doi.org/10.1590/S0103-84782008000200010

Peel, M. C., Finlayson, B. L., \& Mcmahon, T. A. (2007). Updated world map of the Köppen-Geiger climate classification. Hydrology and Earth System Sciences, 11, 1633-1644. https://doi.org/10.5194/hess-11-1633-2007

Petter, F. A., Andrade, F. R., Zuffo, A. M., Monteiro, M. M. S., Pacheco, L. P., \& Almeida, F A. (2016). Doses e épocas de aplicação de potássio no desempenho agronômico do milho no cerrado piauiense. Comunicata Scientiarum, 7(3), 372-382.

https://doi.org/10.14295/cs.v7i3.1218

Rabêlo, F. H. S., Rezende, A. V., Rabelo, C. H. S., \& Amorim, F. A. (2013). Características agronômicas e bromatológicas do milho submetido a adubações com potássio na produção de silagem. Revista Ciência Agronômica, 44(3), 635-643.

https://doi.org/10.1590/S1806-66902013000300028

Raij, B. V., Cantarella, H., Quaggio, J. A., \& Furlani, A. M. C. (1997). Recomendações de Adubação e Calagem para o Estado de São Paulo. (2nd ed.). Campinas: Instituto Agronômico Campinas. p. 285.

Ribeiro, J. E. S., Barbosa, A. J. S., Lopes, S. F., Pereira, W. E., \& Albuquerque, M. B. (2018). Seasonal variation in gas exchange by plants of Erythroxylum simonis Plowman. Acta Botanica Brasílica, 32(2), 287-296. https://doi.org/10.1590/0102-33062017abb0240

Silva, F. L. B., Lacerda, C. F., Neves, A. L. R., Sousa, G. G., Sousa, C. H. C., \& Ferreira, F. J. (2013). Irrigação com águas salinas e uso de biofertilizante bovino nas trocas gasosas e produtividade de feijão-caupi. Irriga, 18(2), 304-317.

https://doi.org/10.15809/irriga.2013v18n2p304

Soares, B. L., Ferreira, P. A. A., Rufini, M., Martins, F. A. D., Oliveira, D. P., Reis, R. P., ... \& Moreira, F. M. S. (2016). Agronomic and economic efficiency of common-bean inoculation with rhizobia and mineral nitrogen fertilization. Revista Brasileira de Ciência do Solo, 40, 1-13. https://doi.org/10.1590/18069657rbcs20150235

Soares, L. A., Furtado, G. F., Andrade, E. M. G., Sousa, J. R. M., Guerra, H. O. C., \& Nascimento, R. D. (2013). Troca de $\mathrm{CO}_{2}$ do feijão-caupi irrigado com água salina e fertilização nitrogenada. Agropecuária Científica no Semiárido, 9(3), 30-37. https://dx.doi.org/10.30969/acsa.v9i3.386

Sousa, M. D. M., Carvalho, C. M., Sabino, R. K., Lopes, P. H., Alcântara, V. S., \& Silvestre, A. C. A. (2013). Efeito da adubação potássica no crescimento do feijão de corda preto. Revista Brasileira de Agricultura Irrigada, 7(1), 66-73.

https://doi.org/10.7127/rbai.v7n100005

Souza, C. A. M., Oliveira, R. B., Martins Filho, S., \& Lima, J. S. (2006). Desenvolvimento 
em campo de espécies florestais em diferentes condições de adubação. Ciência Florestal, 16(3), 243-249. https://doi.org/10.5902/198050981905

Taiz, L., Zeiger, E., Møller, I. M., Murphy, A. (2017). Fisiologia e Desenvolvimento Vegetal. (6th ed.). Porto Alegre: Artmed. p. 888.

Vilela, L., Sousa, D. M. G., \& Silva, J. E. (2004). Adubação potássica. In D. M. G. Sousa, \& E. Lobato (Eds.), Cerrado: correção do solo e adubação (pp. 169-183). Brasília: Embrapa Informação Tecnológica.

Wendling, A., Eltz, F. L. F., Cubilla, M. M., Amado, T. J. C., \& Mielniczuk, J. (2008). Recomendação de adubação potássica para trigo, milho e soja sob sistema plantio direto no Paraguai. Revista Brasileira de Ciência do Solo, 32(5), 1929-1939.

https://doi.org/10.1590/S0100-06832008000500014

\section{Copyright Disclaimer}

Copyright for this article is retained by the author(s), with first publication rights granted to the journal.

This is an open-access article distributed under the terms and conditions of the Creative Commons Attribution license (http://creativecommons.org/licenses/by/4.0/). 